\title{
Profile Characteristics of Maize Farmers in Mahmud-i-Raqi District of Kapisa a Province of Afghanistan
}

\author{
Tamana Kohisatani*, S.V. Prasad, P.V. Satya Gopal and G. Prabhakara Reddy \\ Department of Agricultural Extension, S.V Agricultural College, Tirupati-517502, Chittoor \\ District, Andhra Pradesh, India
}

*Corresponding author

\section{A B S T R A C T}

\section{Keywords}

Profile

characteristics,

Maize farmers,

Extension contact

Article Info

Accepted:

20 June 2018

Available Online:

10 July 2018
The Present investigation was carried out to study the profile characteristics of maize farmers in Mahmud-i-raqi district of Kapisa one of major maize production province in Afghanistan .Ex-post facto research design was followed for the study and a sample of 120respondents were drawn. The results of the study revealed that most of the respondents were young aged $(39.17 \%)$, illiterate middle to school educated (30.00\%),had medium experience in maize cultivation $(63.33 \%)$,small farm size $(58.33 \%)$, had medium mess media exposure $(63.33 \%)$, medium extension contact $(69.17 \%)$, low social participation $(59.17 \%)$, medium scientific orientation $(64.17 \%)$, medium economic orientation $(65.00 \%)$, medium innovativeness $(63.33 \%)$, medium achievement motivation $(66.67 \%)$ and medium deferred gratification $(77.50 \%)$.

\section{Introduction}

Maize enjoys an important position in the existing cropping systems of Afghanistan. It ranks third after wheat and rice in country for its grain production. Maize is grown in almost all the provinces of the country. It is not only consumed by human beings in the form of food grain but it is also used as feed for livestock and poultry besides being a good forage crop. In Afghanistan, it is grown on 0.142 million hectares in all of the provinces in irrigated and rainfed areas. The total production of maize in the country is 0.312 million tons with the average productivity of
2.20 tons per hectare. The average grain yield of maize is not only substantially lower compared with other important maize growing countries even though the soil and climatic conditions of Afghanistan are favorable for maize production Maize is grown twice a year in Afghanistan (Spring and Autumn). Mahmud-i-raqi district of Kapisa province is one of the major maize growing areas of Afghanistan. Farmers are still using traditional low yielding varieties and not adopting the latest production recommendations leading to low yields of maize. The present research paper focuses on the profile characteristics of maize farmers actually studied in the main 
research study. The main study on the adoption of production recommendations of maize farmers would provide better insight into the suggestions made by them which would help in improvement of extent of adoption of new production technologies for increasing production and productivity of maize farmers.

\section{Materials and Methods}

Ex-post-facto research design was used in the present investigation. Mahmud-i-raqi district of Kapisa was purposively selected as maize was being extensively cultivated in the district. Four villages from the district viz., Ashor Khil, Deh Baba Ali, Bazar Murad Khawja and Deh Babi were randomly selected. From each of the selected villages, 30 respondents were selected by following simple random sampling procedure thus, making a total of 120 respondents who were cultivating maize crop. The data were collected by personal interview method through structured interview schedule and analyzed by employing suitable statistical tools like Arithmetic mean, Standard deviation, Frequencies and percentages were used.

\section{Results and Discussion}

The profile characteristics studied in the study were age, education, farming experience, farm size, mass media exposure, extension contact, social participation, scientific orientation, economic orientation, innovativeness, achievement motivation and deferred gratification.

\section{Age}

It is clear from the Table 1 that about 39.17 per cent of the respondents belonged to young age, followed by middle $(35.83 \%)$ and old (25\%) age categories. The probable reason for the above result might be that more than eighty per cent population of Afghanistan are directly and indirectly depend to agriculture, diary and allied activities as the country's development is crippled with frequent societal disturbances, agriculture is the major provider of finance for most of families, hence young and middle aged rural people are preferring agriculture. Old people are retained in the homes as a mark of respect.

\section{Education}

It is evident from the Table 1 that 30 per cent of the respondents were illiterate followed by middle school (20.83\%), high school (20.83\%), and university (17.5\%). No respondent was with institute education. Therefore from the above results it could be concluded that majority of the maize farmers were illiterate. Poor financial status and absence of formal education institutions in nearby might be the probable reasons low educational status. The similar results were presented by Begum (2008), Divaker (2013).

\section{Farming experience}

It is clear from the Table 1 that majority 65 per cent of the respondents were grouped under medium farming experience followed by low $(14.17 \%)$ and high (20.83\%) farming experience. The medium experience of the respondents in farming might be attributed to their younger to middle age. Definitely the farming experience is an important factor which influences the farmers to accept, evaluate and experiment the innovative technologies in their farm. But the richness of farming experience is more important than quantity. Hence, to improve the quality and richness of farming experience the extension agencies have to conduct different extension activities. This was in conformity with the results of Lakpathi (2011), Rathnam (2000), Sivanarayana et al., (2008) and Archana (2012). 


\section{Farm size}

It is transparent from the Table 1 that 58.33 per cent of the respondents were small farmers followed by medium (15.83\%), big (19.17\%) and marginal farmers (6.67\%).It could be inferred from the results that the sub division and fragmentation of the farm land from one generation to another generation was the main cause for declining the land holding size of farmers. Hence the present study also depicted the same trend of more small land holders. The similar results were with Naik (2009) and Rathnam (2000).

\section{Mass media exposure}

It is evident from the Table 1 that 68.33 per cent of the respondents had medium level of mass media exposure followed by high $(18.33 \%)$ and low $(13.34 \%)$ levels of mass media exposure. The possible reason for the above results might be due to presence of few number of mass media channels viz; television, radio, news papers etc. In these channels also the coverage of different aspects of agriculture is less. This result was in agreement with Reddy (1998), Rathnam (2000), Natarajan (2004), Sangeetha (2004), Kishore (2010), Sangeetha (2013) and Krishnamurthy et al. (2016).

\section{Extension contact}

It is revealed from the Table 1 that 69.17 per cent of the respondents had medium extension contact followed by high (18.33\%) and low $(12.50 \%)$ levels of extension contact.

The probable reason for the above trend might be due to the fact that majority of the respondents were small and marginal famers with low level of education and poor economic status, hence they were not going to the extension agencies and research stations. The extension staff is very poor and the number of visits made by the extension staff is also very less. Moreover extension staff might have concentrated their efforts on big farmers rather than small and marginal farmers. Hence the above trend was observed. This finding was in line with the results of Reddy (1998), Rathnam (2000) and Sangeetha (2013).

\section{Social participation}

It is observed from the Table 1 that 59.17 per cent of the respondents had low level of social participation followed by medium $(45.37 \%)$ and high (3.33\%) levels of social participation. From the above results it could inferred that majority of the maize farmers had low level of social participation followed by medium and high levels of social participation.

Most of the respondents are illiterates, small and marginal landholdings, lack of funds, limited resources and do not have contacts with external organizations. Similar results are obtained by Rao (1987).

\section{Scientific orientation}

The findings presented in the Table 1 indicated that 64.17 per cent of the farmers had medium level of scientific orientation, followed by high $(23.33 \%)$ and low $(12.50 \%)$ levels of scientific orientation. Thus, it is inferred that majority of the respondent had medium level of scientific orientation followed by high and low levels of scientific orientation.

This might be attributed to farmers moderate trustworthiness in scientific methods of production, lower or no access to scientific methods of cultivation, as well as medium to low extension participation and mass media exposure. The similar findings are also reported by Sivasubramanian (2003), Neelaveni (2005), Rao (2011) and Krishnamurthy (2016). 
Table.1 Distribution of respondents according to their profile characteristics

\begin{tabular}{|c|c|c|c|c|}
\hline \multirow[t]{2}{*}{ S.No } & \multirow[t]{2}{*}{ Variables } & \multirow[t]{2}{*}{ Category } & \multicolumn{2}{|c|}{ Respondents } \\
\hline & & & Frequency & Percentage \\
\hline \multirow[t]{3}{*}{1} & \multirow[t]{3}{*}{ Age } & Low & 47 & 39.17 \\
\hline & & Medium & 43 & 35.83 \\
\hline & & High & 30 & 25.00 \\
\hline \multirow[t]{6}{*}{2} & \multirow[t]{6}{*}{ Education } & Illiterate & 36 & 30.00 \\
\hline & & Can read and write only & 13 & 10.84 \\
\hline & & Middle school & 25 & 20.83 \\
\hline & & High school & 25 & 20.83 \\
\hline & & Institute & 0 & 0.00 \\
\hline & & University & 21 & 17.50 \\
\hline \multirow[t]{3}{*}{3} & \multirow[t]{3}{*}{ Farming experience } & Low & 17 & 14.17 \\
\hline & & Medium & 78 & 65.00 \\
\hline & & High & 25 & 20.83 \\
\hline \multirow[t]{4}{*}{4} & \multirow[t]{4}{*}{ Farm size } & Below 1 acre of wetland & 8 & 6.67 \\
\hline & & Between 1 to 2 acres of wetland & 70 & 58.33 \\
\hline & & Between 2 to 4 acres of wetland & 19 & 15.83 \\
\hline & & Above 4 acres of wetland & 23 & 19.17 \\
\hline \multirow[t]{3}{*}{5} & \multirow[t]{3}{*}{ Mass media exposure } & Low & 16 & 13.34 \\
\hline & & Medium & 82 & 68.33 \\
\hline & & High & 22 & 18.33 \\
\hline \multirow[t]{3}{*}{6} & \multirow[t]{3}{*}{ Extension contact } & Low & 15 & 12.50 \\
\hline & & Medium & 83 & 69.17 \\
\hline & & High & 22 & 18.33 \\
\hline \multirow[t]{3}{*}{7} & \multirow[t]{3}{*}{ Social participation } & Low & 71 & 59.17 \\
\hline & & Medium & 45 & 37.50 \\
\hline & & High & 4 & 3.33 \\
\hline \multirow[t]{3}{*}{8} & \multirow[t]{3}{*}{ Scientific orientation } & Low & 15 & 12.50 \\
\hline & & Medium & 77 & 64.17 \\
\hline & & High & 28 & 23.33 \\
\hline \multirow[t]{3}{*}{9} & \multirow{3}{*}{ Economic orientation } & Low & 17 & 14.17 \\
\hline & & Medium & 78 & 65.00 \\
\hline & & High & 25 & 20.83 \\
\hline \multirow[t]{3}{*}{10} & \multirow[t]{3}{*}{ Innovativeness } & Low & 17 & 14.17 \\
\hline & & Medium & 76 & 63.33 \\
\hline & & High & 27 & 22.50 \\
\hline \multirow[t]{3}{*}{11} & \multirow[t]{3}{*}{ Achievement motivation } & Low & 24 & 20.00 \\
\hline & & Medium & 80 & 66.67 \\
\hline & & High & 16 & 13.33 \\
\hline 12 & Deferred gratification & Low & 9 & 7.50 \\
\hline & & Medium & 93 & 77.50 \\
\hline & & High & 18 & 15.00 \\
\hline
\end{tabular}




\section{Economic orientation}

It is found from the Table 1 that 65 per cent of the respondents had medium level of economic orientation followed by high $(20.83 \%)$ and low (14.17\%) economic orientation. From the above results it could inferred that majority of the maize farmers had medium economic orientation followed by high and low levels of economic orientation. This trend may be because most of the farmers being marginal and small they do subsistence agriculture. Marketing facilities are very less, only few big and medium farmers market the produce outside their village. Similar findings are also reported by Natarajan (2004) and Obaiah (2004).

\section{Innovativeness}

It is revealed from the Table 1 that 63.33 per cent of the respondents had medium level of innovativeness followed by high (22.50\%) and low (14.17\%) levels of innovativeness. The possible reason for the above trend might be that the farmers with higher education and extension contact were able to update their knowledge and skills time to time and were ready to accept the new technologies. On the other side, as most of the farmers are illiterate and resource poor they lack awareness of new technologies and they are not able to take risk in adoption of such technologies. It was in conformity with Reddy (1998), Mahithakiran (2000), Subrahmanyam (2002), Reddy (2003), Kalyan (2011) and Ashok (2012).

\section{Achievement motivation}

It is found from the Table 1 that 66.67 per cent of the respondents had medium level of achievement motivation followed by low $(20.00 \%)$ and high (13.33\%) levels of achievement motivation. The above results might be because of the reason that most of the respondents are illiterates, traditional and have medium profile characteristics. Many of the farmers were not knowing better planning and goal setting of their farm activities. This finding was in line with the results of Reddy (1994) and Gopinath (2005).

\section{Deferred gratification}

The findings presented in the Table 1 indicated that 77.50 per cent of the respondents had medium deferred gratification followed by high $(15.00 \%)$ and low $(7.50 \%)$ levels. From the above results it could inferred that majority of the maize farmers had medium deferred gratification followed by high and low levels of deferred gratification. This may be because many of the respondents are small and marginal farmers and were doing subsistence agriculture and allied activities for day to day living. This finding was in line with the results of Palaniswamy (1984) and Obaiah (2004).

In conclusion, the findings revealed that majority of the farmers were young aged, illiterate, with medium farming experience in maize cultivation, were small farmers and had medium mass media exposure, medium extension contact, medium social participation, medium scientific orientation, medium economic orientation, medium innovativeness, medium achievement motivation and medium deferred gratification. Hence, it is imperative to focus on the personal and socio-psychological attributes of maize farmers while designing appropriate strategies with training programs and demonstrations to strengthen the various attributes of maize farmers which intern influence their extent of adoption of production recommendations of maize.

\section{References}

Anju, K.K. and Padmananabhan, V.B .2016.Adoption of Kerala Agricultural 
University Recommended Practices of Amaranthus and vegetable cowpea. Journal of Extension Education. 28 (2): 5651-5658.

Begum, M. K. 2008. A study on participation and decision making of woman farmers in rain fed groundnut cultivation. M.Sc.(Ag.) Thesis. Acharya N G Ranga Agricultural University, Hyderabad.

Divaker, S. 2013. A study on attitude and utilization of crop loan by the farmers of Bihar state. M.Sc. (Ag.) Thesis. Acharya N G Ranga Agricultural University, Hyderabad, India.

Fayaz, S .2015.Entrepreneurial Behaviour of cotton farmers in Kurnool district of Andhra Pradesh.M.Sc.(Ag.)Thesis, Acharya N.G.Ranga Agricultural University, Hyderabad, India.

Onumadu, F.N and Osahon, E.E. 2014. Socioeconomic determinants of adoption of improved rice technology by farmers in Ayamelum local government area of Anambra state. Nigeria. International Journal of Scientific \& Technology Research. Volume 3, Issue 1.

Poswal, C.S., Tyagi, B.D., and Mathur, G.P. 2005. Influence of Farmers knowledge level in adoption of improved sugarcane technology. Cooperative Sugar.36 (10): 827-829.
Reddy, M. V. S., Gangadharappa, N. R., Lakshmana Reddy, B. S and Venkatappa, R. A. 2007. Study on profile of the tribal coffee growers and relationship with their attitude and modernization level. Mysore Journal of Agricultural Sciences. 41(4): 525532.

Sharifullah .2016. Potassium fertilization effects on growth and yield of hybrid maize in Kandahar province of Afghanistan. M.Sc. (Ag.) Thesis. Afghanistan National Agricultural Science and Technology University (ANASTU) Kandahar, Afghanistan.

Suramwad, S.R and B.T. Kolgane .2017.A Study of Adoption of Improved Grape Production Technology Followed by Grape Growers. Indian Research journal of Extension Education 17(3): 101-104.

Subhadeeproy and Rekha. 2012. Level of knowledge and extent of adoption of farmers on recommended tuberose production practices. Indian Journal of Extension Education. 48 (1\&2): 78-80.

Wongnaa, C.A., Awunyo-Vitor, D and Bakang, E.A . 2017. Factors affecting adoption of maize production technologies in Ghana. The Journal of Agricultural Science. Aug-Nov: 1624.

\section{How to cite this article:}

Tamana Kohisatani, S.V. Prasad, P.V. Satya Gopal and Prabhakara Reddy, G. 2018. Profile Characteristics of Maize Farmers in Mahmud-i-Raqi District of Kapisa a Province of Afghanistan. Int.J.Curr.Microbiol.App.Sci. 7(07): 2635-2640. doi: https://doi.org/10.20546/ijcmas.2018.707.309 